Scientific Journal Warsaw University of Life Sciences - SGGW

Problems of World Agriculture volume 18 (XXXIII), number 2, 2018: 228-237

DOI: 10.22630/PRS.2018.18.2.50

Maria Parlińska, ${ }^{1}$ Abhishek Pagare ${ }^{2}$

${ }^{1}$ Warsaw University of Life Sciences - SGGW, Poland

${ }^{2}$ Dr. Babasaheb Ambedkar Marathwada University, Aurangabad, India

\title{
Food Losses and Food Waste Versus Circular Economy
}

\begin{abstract}
The article aims to introduce the issue of food waste and all attempts to prevent action. Business and politics are almost interdependent, and any discussion of an economic nature is not complete without a political contribution. The role of politics and politicians in shaping economic activities was and is widely discussed. In the article, there will be a discussion on the problems of food losses and waste in Poland as the member of EU and in India. The idea of the topic came during the tenure of collaboration between representatives of both departments. Conclusions of the study found some similarities and a lot of differences between the countries. Studies have shown that negative attitude of house-hold towards food waste is not frequently reflected in consumers' behavior, despite their fundamental knowledge on how to reduce food waste. Properly selected and presented information will stimulate both consumer's attitude and behavior.
\end{abstract}

Key words: food, circular economy, waste and food waste, food losses

JEL Classification: Q180

\section{Introduction}

All of the socio-economic development projections we have shown are depleting, at an ever faster rate, of land resources, not just fossil resources, but also natural resources, including the nature we depend on through the use of the services of various ecosystems. According to some assessments at the current rate of resource use, by 2050 we will need more than two planets to sustain us, and the aspirations of many people seeking to improve the quality of life will remain unsatisfactory.

Assessing threats, the international community developing a paradigm of sustainable development is increasingly concerned by the prospect of further threatening development and even the preservation of its current status quo in the face of increasing numbers of land, depletion, degraded poverty and emerging conflicts that are linked to earlier trends.

One of the main research problems being formulated concerns measurement how much food is lost and wasted in the world today and how can we prevent food losses. There is not much ongoing research in this area. Scopus database (as of January 2018) includes 1256 documents with 'waste and food waste, food losses' in its title or keywords (in Social Science and Economics). It justifies that insufficient attention appears to be paid to current global food supply chain losses, which are probably substantial in the all world, also in India.

\footnotetext{
${ }^{1}$ doctor habilitated, professor WULS-SGGW, Department of Agricultural Economics and International Economic Relations WULS-SGGW, 166 Nowoursynowska Str., 02-787 Warszawa, e-mail: maria_parlinska@sggw.pl; https://orcid.org/0000-0003-3323-7779

${ }^{2}$ Erasmus+ Grant holder, Department of Management Science, Dr. BAMU, email: abhishek.pagare1@gmail.com
} 
Food is wasted throughout the supply chain, from agricultural production down to the ultimate consumer. However it's necessary to highlights, that in low-, medium- and highincome countries food is to a significant extent wasted at the different consumption stage.

\section{Tasks and Methods}

The article aimed to bring the food losses and food waste problems to the forefront and present the current situation of food waste in chosen countries. The authors also cited directions for action to improve the situation and rational use of unavoidable food waste. The available existing data sources were used, which was the basis for the analysis and conclusion of the necessary actions.

Global response is the recently adopted United Nations General Assembly Resolution 2030 on Sustainable Development, which defines basic goals of development, including in the area of circulation

In the EU, this issue is covered by the Europe 2020 core development strategy, where one of the seven leading projects in Europe, which effectively uses its resources. As a result, the European Commission has put forward proposals for a range of actions, including those outlined in its communications. In: Action Plan for a Europe-Friendly Person; For a closed-loop economy, a zero-waste program for Europe and more recently: Closure of the loop - A circular action plan accompanied by an updated package of measures for a transition to a circulating economy. This package includes, in addition to the specific organizational plan, along with the timetable, legislative proposals for appropriate revisions to the waste management directives. Although the circulation economy covers all areas of activity, the package of legislative solutions focuses on waste in particular, because in this area understanding is greatest and there are already significant acquisitions in some countries, although there are still low recycling rates in other countries.

\section{The difference between food loss and food waste}

"Food loss" refers to food that spills, spoils, incurs an abnormal reduction in quality such as bruising or wilting, or otherwise gets lost before it reaches the consumer. Food loss typically takes place at the production, storage, processing, and distribution stages in the food value chain. It is usually the unintended result of an agricultural process or technical limitation in storage, infrastructure, packaging, and/or marketing. The term food loss measures the decrease in edible food mass resulting from mismanagement, errors and irregularities at the production, distribution and trade stages. The term food waste refers to the irrational economy management processes taking place in the hospitality and households sector (Kołożyn-Krajewska et al., 2014; Wrzosek et al., 2012).

"Food waste" refers to food that is of good quality and fit for consumption, but does not get consumed because it is discarded either before or after it is left to spoil. Food waste typically, but not exclusively, takes place at the retail and consumption stages in the food value chain. It is usually the result of negligence or a conscious decision to throw food away. Although both food loss and waste happen all over the world, food loss tends to be more prevalent in developing countries, while food waste tends to be more prevalent in developed countries. 


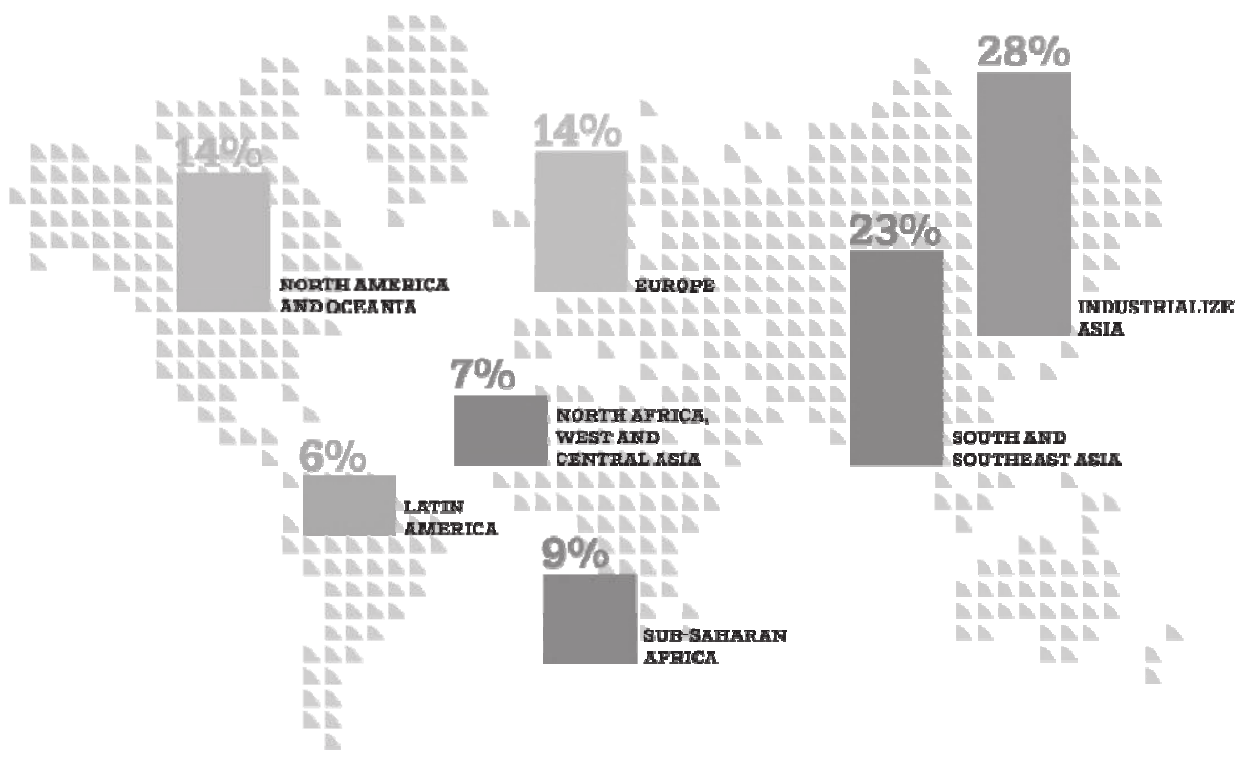

Fig. 1. Total share of global food loss and waste

Source: Graph is obtained from modern farmer web page. World Resources Institute, UNEP, "Reducing food loss and waste", June 2013.

Food waste is regarded as a widespread problem throughout the food industry and occurs in every aspect along the supply chain in the United States as well as worldwide. Food losses and waste depend on specific conditions and may be caused by many di $\square$ erent factors. All factors in the entire food chain carry responsibility in reducing food losses and waste, therefore joint initiatives should be undertaken to reduce this phenomenon. A fundamental change in food system is necessary through a systematic revision of knowledge and awareness among di $\square$ erent actors in the food chain (Kołożyn-Krajewska et al., 2014). One-third of food produced for human consumption is lost or wasted globally, which amounts to about 1.3 billion tons per year. About a third of all that is produced, is wasted, including about $45 \%$ of all fruit and vegetables, $35 \%$ of fish and seafood, $30 \%$ of cereals, $20 \%$ of dairy products and $20 \%$ of meat. Irrational use of food beyond the amount of losses, consumes natural resources what affect at global warming. Moreover it is a barrier for sustainable development for food sector at global scale. Local food waste is a threat for environment because of excessive water and energy consumption and unmet the nutritional needs of societies (Bilska et al. 2014).

Understanding when food loss or waste occurs is important because it affects how we build more sustainable food systems. In general, the European Union and other highincome countries in the region have significantly greater levels of food waste. These countries are launching consumer awareness campaigns and other initiatives to reduce food waste. Middle- and low-income countries aren't wasting nearly as much food in part due to lower supply, lower purchasing power, and less demanding food quality preferences. Instead, they struggle predominantly with food loss issues. 


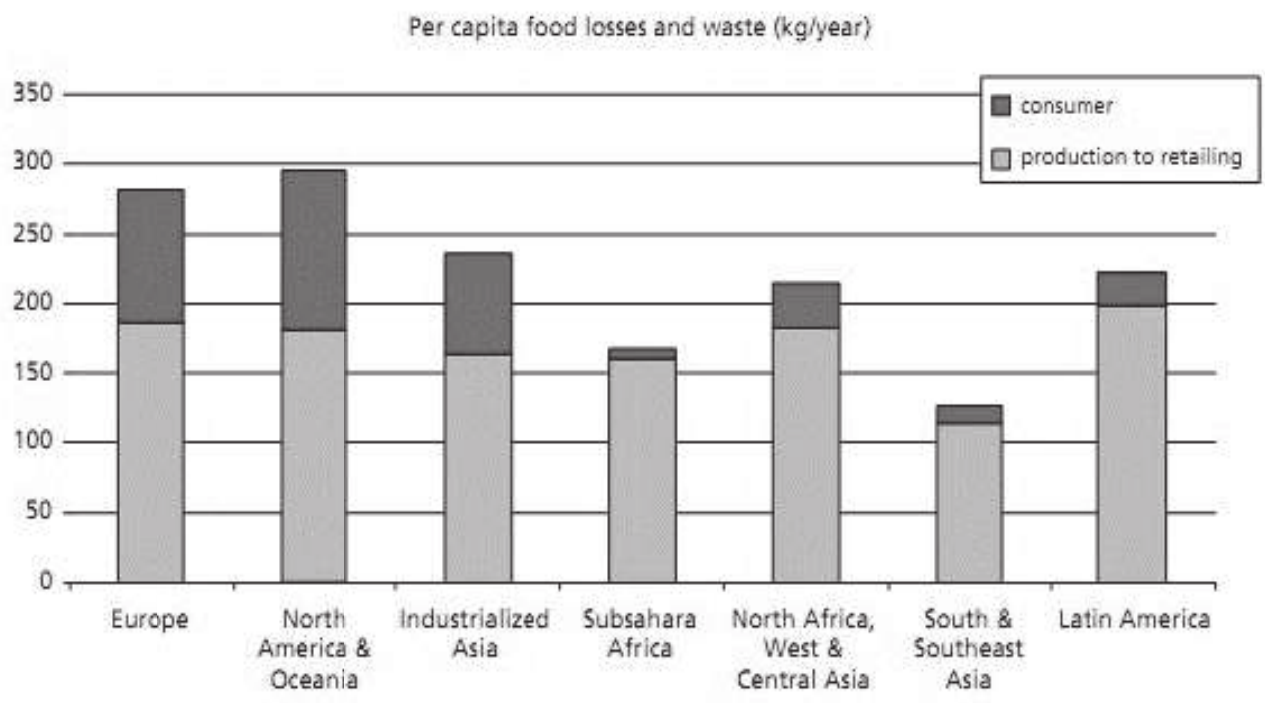

Fig. 2. The above figure is giving information about per capita food losses and waste, at consumption and preconsumption stages, in different regions of the world. As its shown Poland comes in the calculation of Europe and India comes in South and Southeast Asia

Source: Graph is from blog page of Janeal Yancey.

One could pose question why food losses and wastage make such a problem. The old adage "If you can't measure it, you can't manage it" applies especially to food waste. Globally there is very limited data on food loss and waste, partly due to a historic lack of interest and more recently due to the very real difficulties in measuring it. The World Resources Institute (WRI) recognized this in its paper outlining the problem, commenting, "If one does not know how much or where food loss and waste is occurring, how can one be expected to do something about it?

$25 \%$ of fresh water used to produce food is ultimately wasted, even as millions of people still don't have access to drinking water. When we would calculate the figures in cubic kilometers, this is a bit more than an average river. Even though the world produces enough food to feed twice the world's present population, food wastage is ironically behind the billions of people who are malnourished.

Food losses and food waste are quickly becoming a top global issue, because whiles there are millions of families with children starving, others are living in abundance, with many others carelessly throwing food away. Many of us have wasted food in one way or the other, but the real food losses and waste matter is bigger than just consumer food waste.

\section{The Food Losses and Food Waste Scenario of India}

According to current estimates, India's total population will reach 1.45 billion by 2028, similar to China's, and 1.7 billion by 2050, equivalent to nearly the combined 
population of China and the United States today. Given that India is already struggling to feed its population, its current food crisis could worsen significantly in the coming decades.

According to the 2013 Global Hunger Index (GHI), India ranks 63rd, out of the 78 hungriest countries, significantly worse than neighboring Sri Lanka (43rd), Nepal (49th), Pakistan (57th), and Bangladesh (58th). Despite India's considerable improvement over the past quarter-century - its GHI rating had risen from 32.6 in 1990 to 21.3 in 2013 - the United Nations Food and Agricultural Organization believes that $17 \%$ of Indians are still too undernourished to lead a productive life. In fact, one-quarter of the world's undernourished people live in India, more than in all of Sub-Saharan Africa.

More distressing, one-third of the world's malnourished children live in India. According to UNICEF, $47 \%$ of Indian children are underweight and $46 \%$ of those under three years old are too small for their age. Indeed, almost half of all childhood deaths can be attributed to malnutrition - a state of affairs that former Prime Minister Manmohan Singh called a "national shame."

What accounts for India's chronic food insecurity? Farm output has been setting new records in recent years, having increased output from 208 million tons in 2005-2006 to an estimated 263 million tons in 2013-2014. India needs 225-230 million tons of food per year; so, even accounting for recent population growth, food production is clearly not the main issue.

The most significant factor - one that policymakers have long ignored - is that a high proportion of the food that India produces never reaches consumers. Sharad Pawar, a former agriculture minister, has noted that food.

Worth $\$ 8.3$ billion, or nearly $40 \%$ of the total value of annual production, is wasted.

This does not capture the full picture: for example, meat accounts for about $4 \%$ of food wastage but $20 \%$ of the costs, while $70 \%$ of fruit and vegetable output is wasted, accounting for $40 \%$ of the total cost. India may be the world's largest milk producer and grow the second largest quantity of fruits and vegetables (after China), but it is also the world's biggest waster of food. As a result, fruit and vegetable prices are twice what they would be otherwise, and milk costs 50\% more than it should.

It is not only perishable food that is squandered. An estimated 21 million tons of wheat- equivalent to Australia's entire annual crop - rots or is eaten by insects, owing to inadequate storage and poor management at the government-run Food Corporation of India (FCI). Food-price inflation since 2008-2009 has been consistently above $10 \%$, (except for 2010-2011, when it was "only" 6.2\%); the poor, whose grocery bills typically account for $31 \%$ of the household budget, have suffered the most.

There are several reasons why so much perishable food is lost, including the absence of modern food distribution chains, too few cold-storage centers and refrigerated trucks, poor transportation facilities, erratic electricity supply, and the lack of incentives to invest in the sector. The Indian Institute of Management in Kolkata estimates that cold-storage facilities are available for only $10 \%$ of perishable food products, leaving around 370 million tons of perishable products at risk.

The FCI was established in 1964 primarily to implement price-support systems, facilitate nationwide distribution, and maintain buffer stocks of staples like wheat and rice. However, mismanagement, poor oversight, and rampant corruption mean that the FCI, which gobbles up $1 \%$ of GDP, is now part of the problem. Former Food Minister K. V. Thomas called it a "white elephant" that needs to be revamped "from top to bottom". 
However, the government has instead tried to end shortages by increasing production, without considering that up to half of the food will be lost.

India will not have enough arable land, irrigation, or energy to provide enough nutritious food to India's future 1.7 billion people if $35-40 \%$ of food output is left to rot. The new Modi government should, therefore, consider alternative ways to solve India's food crisis.

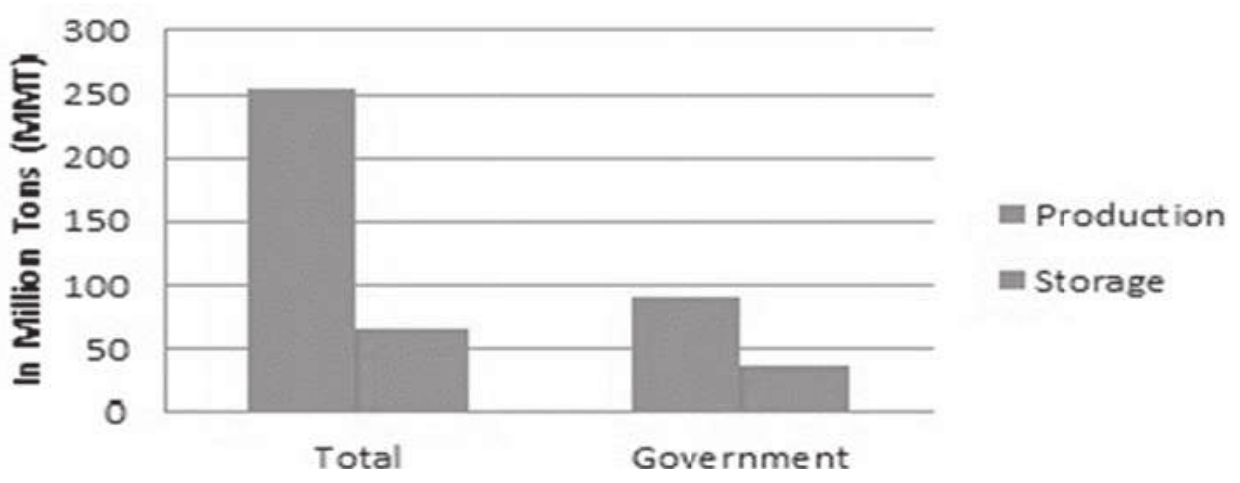

Fig. 3. The figure above is information about India's total food grain in the year 2012-13. Moreover, its total Production and Storage capacity

Source: Graph is from development outlook web page. Production data is from State Food Secretaries; Storage data is from Credit Analysis \& Research Ltd (CARE Ratings) *Government 'production' refers to amount procured by the government from total production.

Food losses and food wastage in India is a serious concern. Indians waste as much food as the whole of United Kingdom consumes. A statistic that may not so much indicative of their love of surfeit, as it is of their population. Still, food wastage is an alarming issue in India. India's street and garbage bins, landfills have sufficient proof to prove it. Weddings, canteens, hotels, social and family functions, households spew out so much food.

According to the United Nations Development Programme, up to $40 \%$ of the food produced in India is wasted. About 21 million tonnes of wheat is wasted in India, and 50\% of all food across the world meets the same fate and never reaches the needy. In fact, according to the agriculture ministry, Rs. 50,000 crore worth of food produced is wasted every year in the country.

The theme for this year's World Environment Day campaign is 'Think Eat Save.' It is an anti-food wastage and food loss campaign aimed at reducing the wastage footprint. Wastage of food is not indicative of only hunger or pollution, but also many economic problems in the economy, such as inflation. Only government policies are not responsible for the problems we are facing today, but our culture and traditions are also playing a lead role in this drama. In India, the bigger the wedding, the larger the party and the more colossal the waste.

The number of hungry people in India has increased by 65 million more than the population of France. According to a survey by Bhook (an organization working towards reducing hunger) in 2013, 20 crore Indians sleep hungry on any given night. About 7 million children died in 2012 because of hunger/malnutrition.

- Acres of land are deforested to grow food. Approximately $45 \%$ of India's land is degraded primarily due to deforestation, unsustainable agricultural practices, and excessive groundwater extraction to meet the food demand; 
- 300 million barrels of oil are used to produce food that is ultimately wasted.

Tackling Food Waste In India.

Food wastage is fast assuming serious dimensions. According to the Food and Agriculture Organization (FAO), a staggering 1.3 billion tonnes of food is being wasted annually. The FAO report further states that one-third of the total global food production is wasted, costing the world economy about $\$ 750$ billion or Rs47 lakh crore. This alarming increase in food wastage is generating nearly 3.3 billion tonnes of greenhouse gas emissions, thereby severely impacting the environment. The wastage of rice, in particular, has serious ramifications for the environment as decaying rice releases methane, a potent global warming gas.

Food wastage is an issue that has a global scale. According to a report by the National Resources Defense Council (NRDC), 40 per cent of the food goes uneaten in the US, whereas in Asia, India and China cause a loss 1.3 billion tons of food wastage every year. In terms of overall food waste - agricultural produce, poultry, and milk - India rank seventh, with the Russian Federation at the top of the list.

India's lower ranking is because most of the countries ranking above it utilize much of their land in raising poultry, while a major chunk of land in India is under agriculture and this explains the highest wastage of cereals, pulses, fruits and vegetables that occurs in India.

A recent study conducted by Indian Institute of Management, Kolkata, revealed that only 10 percent of foods get cold storage facility in India, this factor, accompanied by inappropriate supply chain management, and has resulted in India becoming a significant contributor towards food wastage both at pre and post-harvest waste in cereals, pulses, fruits, and vegetables. India ranks 63 among 88 countries in Global Hunger Index with 20 crore Indians sleeping hungry on any given night, but in spite of this, nearly 21 million tons of wheat are wasted in India each year instead of reaching the needy.

Apart from the wastage of the food produced, the resources lost in the form of inputs during food production are also considerable. For instance, 25 percent of fresh water, used to produce food, is ultimately wasted, even as millions of people still don't have access to drinking water. In addition, approximately 45 percent of India's land is degraded primarily due to deforestation, unsustainable agricultural practices, and excessive groundwater extraction to meet the food demand.

Besides this, nearly 300 million barrels of oil used to produce food is also ultimately wasted. Taking all of it into consideration, the actual worth of money per year in India from food wastage is estimated at a whopping Rs58, 000 crores.

The Government has made many efforts to rein in food wastage, but clearly, the depth of the problem is such that the impact of these efforts is hardly up to the mark. In order to make progress in reducing the burden of this problem, the Government needs to primarily contain the excessive wastage in transportation and improve storage facilities that are currently 50 per cent less than required. Besides this, the Government must also focus on food processing technologies that are both advanced and affordable so that food preservation practices can be encouraged thereby saving food from wastage.

India should also take a cue from global practices that are both unorthodox and innovative in order to tackle food wastage problem. For instance, France has passed unanimous legislation requiring supermarkets to either give unsold food to charity or send it to farmers for use as feed and fertilizer.

Similarly, institutions in Canada are recovering unused and unspoiled food from retailers, manufacturers, restaurants, and caterers and sending them to charities, in the 
process delivering ingredients for over 22,000 meals daily. These powerful initiatives have made a big difference in how these countries have approached a vexing issue.

India can effectively use technology to script a new chapter in the prevention of food wastage. The Government can speed up research in Nano technology with the help of which eco-friendly and healthy food preservation applications can be invented that are helpful in preserving food for longer duration and keeping farm produce fresh.

In addition to these efforts, the Government must make it mandatory for the food retailers across the country to adopt technology standards that allow incentives for the customer to purchase perishable products that are approaching their expiration dates. This will help reduce food wastage, maximizes grocery retailer revenue, and effectively reduces the global carbon footprint.

\section{Results and discussion}

Undoubtedly, activities will be covered by other sectors, since the circulation economy should cover all activities comprehensively, also taking into account, for example: impact of climate change on renewable resources and ecosystem services. This is a challenge not only from resource exhaustion but also on the extent to which economic benefits can be achieved. According to some studies, in only three sectors (transport, food, construction), unused capacities are estimated at around $€ 7.2$ billion (with the EU budget in $2014-€ 13.9$ billion). This shows a huge untapped potential.

Transformation to a circulating economy is essential because of depletion of resources and economic and social effects. The key question to ask is how to influence action to make the most effective use of existing potential for the country's development.

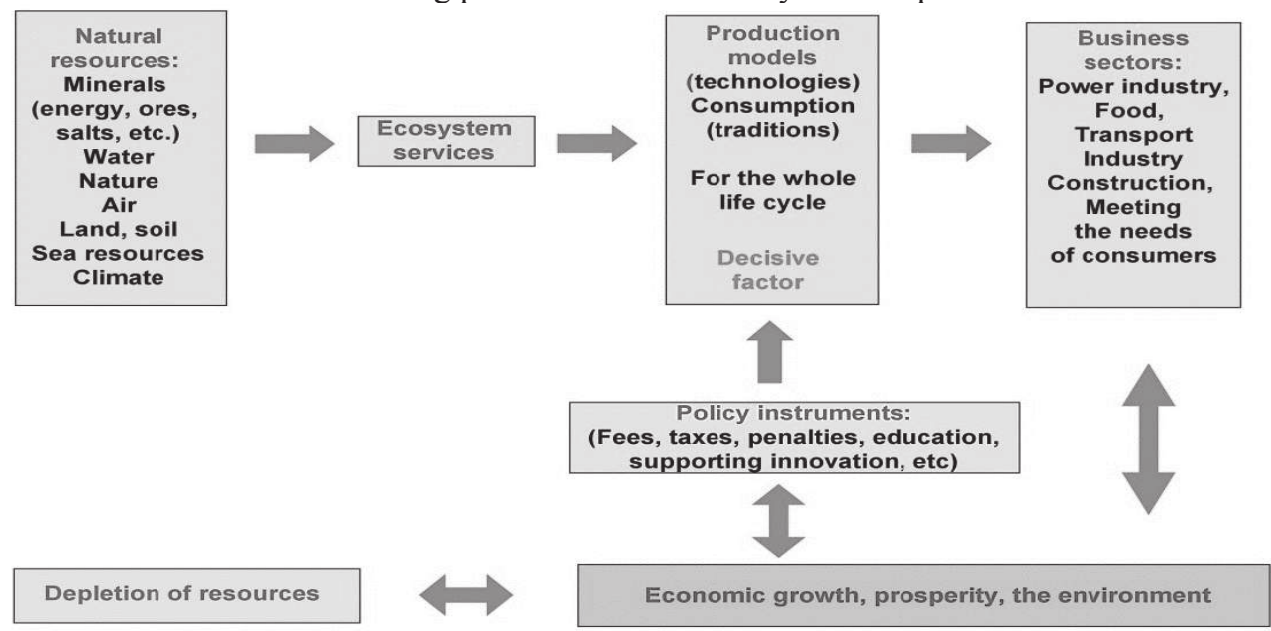

Fig. 4. Diagram of the economy in terms of resource use

Source: own elaboration.

On the basis of the analysis of factors influencing development (which is presented in the simplified illustration below), it can be stated that production and consumption patterns 
that are important to each other are significant. Namely, supply influences consumption, and consumer needs and expectations influence the size of production. Therefore, attention should be paid to the aforementioned elements. One of the critical sectors of the circulation economy is the production and use of food.

According to the study cited above, only $69 \%$ of the food produced in the EU is consumed in the EU. About 100 million tons. Losses during the various phases of the production and consumption chain are $14.2 \%$ and $14.7 \%$ respectively, processing and packaging $-3.9 \%$, distribution $-2.2 \%$, consumption $-10.6 \%$. The minimisation of waste in food and catering services is a challenge directly affecting European hospitals, where up to $30 \%$ of the food served is wasted, according to some studies. (Williams, P.,2011).

According to the Food and Agriculture Organization (2015), around 800 million people do not have enough to eat.

In Poland, according to available Eurostat data, the loss was about 9 million tonnes ( $73 \%$ in processing and $23 \%$ of households). Due to the lack of accurate, up-to-date data, in order to determine the potential benefits of counteracting food waste, it can be reasonably assumed that the waste of food in Poland is slightly lower than in the EU, amounting to about $25 \%$. Taking into account that the annual value of the food market in Poland is at 243bn PLN, it can be calculated that the value of wasted food per year amounts to approximately $61 \mathrm{bn}$ PLN, including 14bn PLN in households (this amount should be adjusted because it recognizes the food waste from the process of its use and calculates the average food prices, and most often the food is dumped. It is important to note that due to the lack of availability of up-to-date data (with a noticeable increase in the amount of food consumed by households in individual EU countries), the value of wasted food by the household sector in Poland can be estimated at around 10 billion PLN a year. The above quotations indicate that it is worthwhile to take action to reduce food waste, the more that apart from direct profits, in order to determine the potential benefits of counteracting food waste, a whole series of additional effects in the form of:

- support the poor population by exploiting food so-far,

- improving the environment by eliminating the storage of unused food,

- reducing greenhouse gas emissions and air pollution,

- Use of raw materials in organic waste.

Counteracting the waste of food can be at various stages of its formation, consumption and waste management. Each of the food life cycles has its characteristics that vary from product to product. Efficiency at all stages can be influenced by action at local, regional and central level.

The hierarchy of importance of actions should be presented in a specific order: to counteract the loss. In the organization of the circulation economy, the following groups should be involved: local community, local government, local producers, educational authorities, non-governmental organizations.

From their initiatives, they will depend on the types of activities undertaken and the results. 


\section{Conclusions}

The World Economic Forum warns that food shortages represent one of the biggest risks to global stability over the next decades as countries are increasingly affected by climate change. Even though the world produces enough food to feed twice the world's present population, food wastage is ironically behind the billions of people who are malnourished. It is time to recognize this colossal scale of waste and take appropriate action that not only benefits humanity but the environment as well.

\section{Bibliography}

Cabin, M.A. (2013). Analysis of strategic planning tools. Print: "Young scientist”. № 11, 500-503.

Ellen Macarthur Foundation, McKinsey 2014. Centre for Bossiness and Environment and Sun, Growth within: A circular Economy Vision for a competitive Europe.

European Commission. Preparatory study on food waste across EU27, Technical Report - 2010 - 054

Food and Agriculture Organization. (2015). The State of Food Insecurity in the World. Rome: FAO.

Food losses and waste in the context of sustainable food systems, HLPE 8, 2014.

http://ec.europa.eu/food/safety/food_waste/good_practices/awareness_information_education/index_en.htm.

http://ec.europa.eu/food/safety/food waste/index en.htm. 4.03.2016.

http://feedbackglobal.org/get-involved/are-you-a-business/. 11.03.2016.

http://www.developmentnews.in/tackling-food-wastage-india/.

http://www.euractiv.com/section/agriculture-food/news/french-food-waste-could-feed-ten-million-people/?nl ref $=14022510$

http://www.independent.co.uk/news/world/europe/italy-supermarkets-food-waste-law-charity-a6937001.html.

http://www.lastminutemarket.it/media_news/english/.

http://www.portalspozywczy.pl/raporty/rynek-spozywczy-w-polsce-w-2015-r-warty-243-mld-zl,116782 0.html.

https:/www.psit.in/clubs@psit/THEECOCLUB/articles/Food\%20Wastage\%20In\%20India\%20A\%20Serious\%20 Concern.pdf.

https:/www.weforum.org/agenda/2014/08/india-perishable-food-waste-population-growth/.

$\mathrm{KOM}(2010) 2020$.

$\operatorname{KOM}(2011) 571$ wersja ostateczna.

KOM(2011)0571.

KOM(2014)398.

$\mathrm{KOM}(2014) 614$

UN General Assembly Resolution A/RES/70/1 Transforming our world: the 2030 Agenda for sustainable development, 21.10.2015.

Williams, P., Walton, K. (2011). Plate waste in hospitals and strategies for change. E-SPEN. The European E-Journal of Clinical Nutrition and Metabolism, 6(6), e235-e241.

Wrzosek, M., Kołożyn-Krajewska, D., Krajewski, K. (2012). Nieracjonalne wykorzystanie żywności perspektywa globalna i odpowiedzialności społecznej (Irrational use of food - global perspective and social responsibility). Prace Studentów i Młodych Pracowników Nauki. Teoria i praktyka zarządzania przedsiębiorstwem. Wybrane zagadnienia, 4, 59-72.

For citation:

Parlińska M., Pagare A. (2018). Food Losses and Food Waste Versus Circular Economy. Problems of World Agriculture, 18(2), 228-237; DOI: 10.22630/PRS.2018.18.2.50 